\title{
$\mathrm{EV}$ 用六相極数切換誘導電動機の過渡特性解析法
}

正員 水野 孝行 (明電舎)
正員廣塚 功 (中部大学)
正員 足利 正 (明電舎)

\author{
正員 坪井 和男 (中部大学) \\ 准員 鈴木信太郎 (中部大学) \\ 正員松田 功 (明電舎)
}

\section{Transient Performance Analysis of A Six-Phase Pole Change Induction Motor for Electric Vehicles}

Takayuki Mizuno, Member (Meidensha), Isao Hirotsuka, Member (Chubu University), Tadashi Ashikaga, Member (Meidensha),
Kazuo Tsuboi, Member (Chubu University)

Shintaro Suzuki, Associate Member (Chubu University)

Isao Matsuda, Member (Meidensha)

We have already proposed a six-phase pole change induction motor (six-phase PCIM) for electric vehicles (EV), and have been making clear about its operation principle and steady state characteristics. The six-phase PCIM further expands the constant power operation range using the pole change technique without mechanical contactors, therefore it possesses the superb characteristics to miniaturize the EV's driving systems.

This paper proposes a new analyzing method for the six-phase PCIM in order to derive the basic equations which can be utilized to analyze the transient phenomena caused by pole change and to create the control methods. First, a "six-phase tensor-transformed rotational $d-q$ axis" (provisional name) will be defined, and its physical meanings will be made clear. By using this axis, the voltage and torque equations which can uniformly deal with the steady state and the transient state will be derived.

Next, comparative examinations between the measured results and the simulated results regarding the voltage, current and torque characteristics on the steady state and the transient state at the pole change operation and the both poles dual operation will be achieved. Through these examinations, the propriety of this theory and its effectiveness in the further detail performance analysis and the application to the control method for the six-phase PCIM will be discussed.

キーワード：電気自動車, $\mathrm{EV}$ 用電動機, 誘導電動機, 過渡特性解析法, 六相絶対変換 $d-q$ 軸, 極数切換電動機

\section{1. まえがき}

電気自動車(以下，EVと略記) 駆動用電動機は，小形軽 量, 保守容易，構造堅牢といった基本的な特徴に加え，制 御性に優れるとともに低速域で高トルクを発生し，高速域 で広範囲の定出力運転が可能である必要がある(1)。かご形 誘導電動機（以下，IMと略記）は，上記の基本的な特徵を 満足することはもとより，ベクトル制御により低速高トル ク運転および広範囲な定出力運転も比較的容易に行うこと ができ，EV用電動機として一つの主流になるものと期待 されている(2)。

著者らは，EV用誘導電動機の運転特性をさらに改善す るため, 極数比 $2: 1 の$ 単一巻線極数切換方式を忘用した六 相極数切換誘導電動機 (以下，六相PCIMと略記) を提案 し，その基本原理および定常特性を明確にした(3)〜(9)。 六相PCIMは，極数切換を利用して，電動機の体格およ
び電流を增大させることなく定出力運転範囲の一層の应大 が可能となること，極数切換のための關閉器が不要とな り, システムとして小形化できること，などの優れた特長 を有している(9)。

六相PCIMのEVへの適用を考えた場合，極数切換時の過 渡特性の明確化，極数切換およびその前後における連続的 な制御方式の確立なども重要な課題となる。周知のよう に，一般的な三相IMに対しては，これらの検討を行うため の基整的解析法およびそれに基づく電圧方程式など，既に 十分なものとなっている。しかし，六相PCIMでは，位相 角 $\pi / 3[\mathrm{rad}] の$ 対称六相交流と位相角 $2 \pi / 3[\mathrm{rad}] の$ 対称六 相交流 (以下，二倍角対称六相交流と仮称)とを切り換える ことにより極数切換が行われること ${ }^{(9)}$ ，これらの六相交流 を同時に加えることによって，極数切換時のトルク変動を 少なくする制御方式も可能となること(10)などの点から，従 来の三相I Mを対象とした解析理論をそのまま適用するに 
は無理がある。

任意の多相交流を扱い得る解析法としては，著者の一人 が既に提案している多相絶对変換対称軸(11)がある。この座 標軸を用いると，一般多相機の解析，時間的および空間的 高調波を考慮した解析などが極めて容易となる利点があ る(12)。しかし，取り扱う諸量が複素数となることから，過 㴖現象の数值計算および可変速制御方式の構築などに応用 寸る場合には難しい面もある。したがって，六相PCIMに 对して, 以上の点を考慮できる適切な解析法の確立が必要 である。

本論文では，六相PCIMの過渡現象の解析や制御方式の 構䇣に応用できる基整方程式の導出を目的として，対称六 相交流および二倍角対称六相交流を同時に，かつ寒数で扱 い得る新しい解析法を検討する。この種の解析において は，三相IMに適用されているような回転 $d-q$ 軸(13)を用い ると，従来技術との整合性もとれて便利であるので，まず 対称六相交流および二倍角対称六相交流のそれぞれに対応 する 2 種類の回転座標軸を用意し, "六相絶対変換回転 $d-q$ 軸"(仮称) (3)を定義する。また，各々の座標軸に対する物理 的意味も明確にする。

次に，この座標軸を用いて，定常状態から過渡状態ま で，対称六相交流および二倍角対称六相交流をそれぞれ単 独に，あるいは同時に加えた場合などにおいて，統一的に 取り扱い得る電压方程式およびトルクの式を遒出する。注 目すべきは，対称六相交流に対する電圧方程式と二倍角対 称六相交流に対するそれとを，まったく独立に扱うことが できる点であり，最終的に得られた電流およびトルクなど を加え合わせれぱよいことになる。さらに，定常状態およ び過渡状態における電流，トルク特性などの実測結果とシ ミュレーション結果との比較検討を通して，本理論の妥当 性を検証するとよもに，六相PCIMの特性解析および制御 方式への応用などに対して，その有用性を明らかにする。

\section{2. 六相PCIMの解析}

$<2.1>$ 解析上の仮定と解析モデル 六相PCIMは，基 本的に単一巻線極数切換方式を応用して，各相巻線に流す 電流の位相と周波数とを制御して極数比 $2: 19$ 極数切換を 行うものである(9)。したがって，任意の極数での構成が 可能となるが、ここで位高速側，すなわち極数の小さい側 を基準とし，その極対数をか’とする。巻線の位置などを電 気角で表す場合にはこの基準に従うものとする。以下，極 数の小さい側を基淮とする座標系を基淮座標系と称する。

また，解析に当たっては，2p'極あるいは4 $4 p^{\prime}$ 極上して の時間的および空間的基本波成分のみを考慮することと し，鉄損，磁気飽和および漂遊負荷損などは無視できるも のとする。実際の駆動シスデムでは，電源にインバータ(以 下，INVと略記)を用いることになり，高調波成分の影響を受 けることも考えられる。しかし，一般にEV用INVの主回路素 子にはIGBTが採用され，搬送周波数を高くすることで，騷 音，トルク脈動などの高調波の影響が低減されている。した
がってここでの仮定のように基本波成分のみに着目した場 合でも，後述するように実用的には十分な解析が可能とな る。ただし，固定子鉄損は文献(13)を参照して容易に導入す ることができるので，最終的に得られた電圧方程式に追加 するものとする。

六相PCIMの解析モデルは，以上の仮定および前論文 ${ }^{(9)}$ にしたがって六相PCIMの巻線配置の1極対分のみを考虑 すれば，図1のように表すことができる。ただし，a，b， ‥ f は, 固定子の各相巻線, $\mathrm{g}, \mathrm{h}, \cdots, 1$ は, 回転子の各相巻 線を表す。回転子位置角 $\theta$ は固定子 $\mathrm{a}$ 相巻線と回転子 $\mathrm{g}$ 相巻 線とのなす角度 (基準座標系電気角)で， $2 p^{\prime}$ 極としての電源 角周波数および滑りを用いて表すと(1)式, 同じく $4 p^{\prime}$ 極と しての諸量を用いて表すと(2)式となる。

$2 p^{\prime}$ 極 : $\theta=\left(1-s_{1}\right) \omega_{1} t+\phi$

$4 p^{\prime}$ 極 : $\theta=(1 / 2)\left(1-s_{2}\right) \omega_{2} t+\phi$

ここに， $s_{1}$ および $s_{2}: 2 p^{\prime}$ 極および $4 p^{\prime}$ 極としての滑

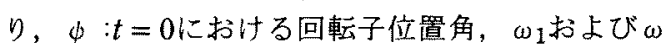

${ }_{2}: 2 p^{\prime}$ 極抢よび $4 p^{\prime}$ 極としての電源角周波数

$<2.2>$ 六相絶対变換回転 $d-q$ 軸の定義 動作原理の詳 細は前論文 ${ }^{(9)} に$ 譲ることにするが，図1において $2 p{ }^{\prime}$ 極と するためには，向かい合う巻線がギャップ面に対して異な る磁極を作るように電圧を加えればよく，各相の電圧は (3)式に示すような対称六相交流となる。

$$
\begin{aligned}
& v_{a 1}=V_{1 m} \cdot \cos \left(\omega_{1} t+\phi_{1}\right) \\
& v_{b 1}=V_{1 m} \cdot \cos \left(\omega_{1} t+\phi_{1}-\pi / 3\right) \\
& v_{c 1}=V_{1 m} \cdot \cos \left(\omega_{1} t+\phi_{1}-2 \pi / 3\right) \\
& v_{d 1}=V_{1 m} \cdot \cos \left(\omega_{1} t+\phi_{1}-3 \pi / 3\right) \\
& v_{e 1}=V_{1 m} \cdot \cos \left(\omega_{1} t+\phi_{1}-4 \pi / 3\right) \\
& v_{f 1}=V_{1 m} \cdot \cos \left(\omega_{1} t+\phi_{1}-5 \pi / 3\right) \\
& \text { ここに， } V_{1 m} \text { およ゙゙ } \phi_{1}: \text { 対称六相交流の相電圧の }
\end{aligned}
$$$$
\text { 最大値および位置角 }
$$

また，4p'極とするためには，逆に向かい合う巻線が同極 となるように電圧を加えればよく，各相巻線の電圧は (4) 式に示すような二倍角対称六相交流となる。

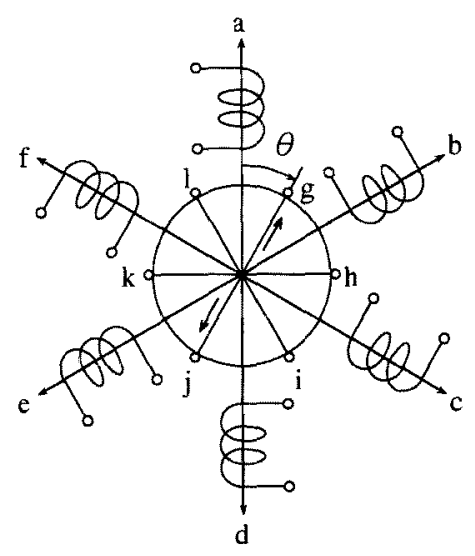

図1 六相PCIMの解析モデル

Fig. 1. Analytical model for the six-phase PCIM. 


$$
\begin{aligned}
& v_{a 2}=V_{2 m} \cdot \cos \left(\omega_{2} t+\phi_{2}\right) \\
& v_{b 2}=V_{2 m} \cdot \cos \left(\omega_{2} t+\phi_{2}-2 \pi / 3\right) \\
& v_{c 2}=V_{2 m} \cdot \cos \left(\omega_{2} t+\phi_{2}-4 \pi / 3\right) \\
& v_{d 2}=V_{2 m} \cdot \cos \left(\omega_{2} t+\phi_{2}\right) \\
& v_{e 2}=V_{2 m} \cdot \cos \left(\omega_{2} t+\phi_{2}-2 \pi / 3\right) \\
& v_{f 2}=V_{2 m} \cdot \cos \left(\omega_{2} t+\phi_{2}-4 \pi / 3\right) \\
& \text { ここに, } V_{2 m} \text { および } \phi_{2} \text { : 二倍角対称六相交流の相 }
\end{aligned}
$$$$
\text { 電圧の最大值および位置角 }
$$

六相PCIMの実際の制御方式については今後の課題とす るが，対称六相交流と二倍角対称六相交流とを，それぞれ 独立に加える場合と, 極数切換時などにおいてはトルクの 変動を防止するために同時に加える場合(10)とが考えられ る。したがって, 制御方式によっては $2 p$ 極としての回転 磁界と $4 p$ 極としての回転磁界とが各々独立して, あるい は同時に存在する可能性がある。

そこで，いかなる運転状態においても統一的な解析が可 能となるように，基準となる $2 p$ 極に対する回転座標軸 ( $d_{1}-q_{1}$ 軸) と, $2 p$ '極に対して2倍の角度で表し得る $4 p^{\prime}$ 極に 対する回転座標軸 $\left(d_{2}-q_{2}\right.$ 軸) とを用意し, 六相絶対変換回 転 $d-q$ 軸 (仮称) を定義する。以下, 多相絶対変換対称座標 軸(11)の呼称にならい，2p’極に対する回転座標軸を基準 $d-q$ 軸, $4 p$ '極に対する回転座標軸を二倍角 $d-q$ 軸と称する ことにする。

各座標軸の物理的意味については以下のようである。

（1）基準 $d-q$ 軸 $\left(d_{1}-q_{1}\right.$ 軸） $2 p$ 極の2極分を基本波の1 周期 $(2 \pi[\mathrm{rad}])$ とした基準座標系において, 任意の角速度 で回転する直交二軸である (図 $2(\mathrm{a})$ 参照)。基準 $d-q$ 軸の 回転角速度を $2 p^{\prime}$ 極の回転磁界に同期させると, 位相角が $\pi / 3[\mathrm{rad}]$ からなる対称六相交流は, 周波数に無関係な直 流量となる。また, 位相角が $2 \pi / 3[\mathrm{rad}]$ からなる二倍角対 称六相交流の場合, 基準 $d-q$ 軸上での值は 0 となる。固定 子についての相軸と基準 $d-q$ 軸との諸量の間には, 図2(a) より以下の関倸がある。

$$
\left.\begin{array}{rl}
v_{d s 1}= & k\left\{v_{a 1} \cdot \cos \theta_{s 1}+v_{b 1} \cdot \cos \left(\theta_{s 1}-\pi / 3\right)+\right. \\
& \left.\cdots+v_{f 1} \cdot \cos \left(\theta_{s 1}-5 \pi / 3\right)\right\} \\
v_{q s 1}= & k\left\{-v_{a 1} \cdot \sin \theta_{s 1}-v_{b 1} \cdot \sin \left(\theta_{s 1}-\pi / 3\right)-\right. \\
& \left.\cdots-v_{f 1} \cdot \sin \left(\theta_{s 1}-5 \pi / 3\right)\right\} \\
& \cdots \cdots \cdots \cdots \cdots \cdots \cdots \cdots \cdots \cdots \cdots \cdots \cdots \cdots \cdots \cdots \cdots \cdots
\end{array}\right\}
$$
軸電圧および $q$ 軸電圧， $\theta_{s 1}$ : 固定子基準 $d-q$ 軸の 回転角, $k:$ ユニタリ行列とするための係数

(2)二倍角 $d-q$ 軸 $\left(d_{2}-q_{2}\right.$ 軸) $2 p^{\prime}$ 極の 2 極分を $4 \pi$ [rad]とした二倍角座標系において, 任意の角速度で回転 する直交二軸である (図 $2(\mathrm{~b})$ 参照)。二倍角 $d-q$ 軸の回転角 速度を $4 p$ 極の回転磁界に同期させると，位相角が $2 \pi / 3$ [rad]加らる二倍角対称六相交流は周波数に無関係な直 流量となる。また，位相角が $\pi / 3[\mathrm{rad}]$ からなる対称六相交 流の場合, 二倍角 $d-q$ 軸上での值は0となる。固定子につ

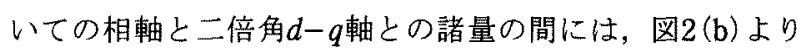
以下の関係がある。

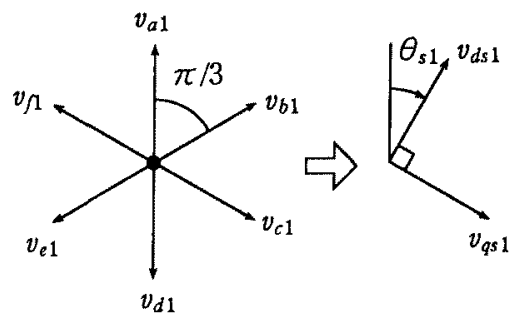

(a) 基準 $d-q$ 軸

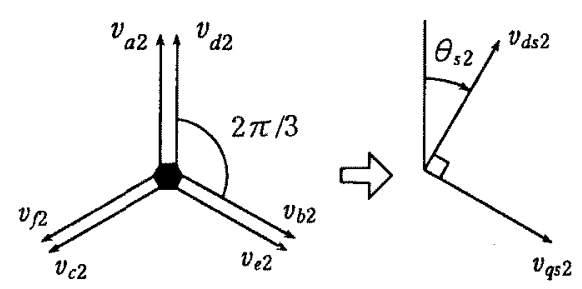

(b) 二倍角 $d-q$ 軸

図2 六相絶対変換回転 $d-q$ 軸の定義

Fig. 2. Definition of six-phase tensortransformed rotational $d-q$ axis.

$$
\begin{array}{rl}
v_{d s 2}= & k\left\{v_{a 2} \cdot \cos \theta_{s 2}+v_{b 2} \cdot \cos \left(\theta_{s 2}-2 \pi / 3\right)+\right. \\
& \left.\cdots+v_{f 2} \cdot \cos \left(\theta_{s 2}-10 \pi / 3\right)\right\} \\
v_{q s 2}= & k\left\{-v_{a 2} \cdot \sin \theta_{s 2}-v_{b 2} \cdot \sin \left(\theta_{s 2}-2 \pi / 3\right)-\right. \\
& \left.\ldots-v_{f 2} \cdot \sin \left(\theta_{s 2}-10 \pi / 3\right)\right\} \\
& \ldots \cdots \cdots \cdots \cdots \cdots \cdots \cdots \cdots \cdots \cdots \cdots \cdots \cdots \cdots \cdots \cdots \cdots \cdots \cdots \\
こ こ & k, v_{d s 2} \text { および } v_{q s 2}: \text { 固定子二倍角 } d-q \text { 軸上 }
\end{array}
$$

$の d$ 軸電圧および $q$ 軸電圧, $\theta_{s 2}$ : 固定子二倍角 $d-q$ 軸の回転角

以上の座標軸を組み合せ，ユニタリ変換が可能となるよ うに，各座標軸の零相軸成分および係数kの值を決定する と, 固定子巻線についての最終的な六相絶対変換回転 $d-q$ 軸の変換行列として（7)式を定義することができる。ただ し, この場合, $k=1 / \sqrt{3}$ となる。

詳細は後述するが, この六相絶対変換回転 $d-q$ 軸を用い ると，2p'極を形成する対称六相交流の電圧㧍よび電流成 分は基準 $d-q$ 軸に，4p'極を形成する二倍角対称六相交流の 電圧および電流成分は二倍角 $d-q$ 軸にのみ関係することに なり, 各々の極数での単独運転時の特性のみならず，両極 同時運転時の特性, 極数切換時の過渡状態までも統一的 に，かつ簡便に取り扱うことができる利点がある。

なお，この考え方を延長して，三倍角 $d-q$ 軸，四倍角 $d-q$ 軸， $\cdots \cdot$, を考慮すれば，多相絶対変換対称軸(11)に対 応する回転 $d-q$ 軸として，任意の多相交流を取り扱い得る "多相絶対変換回転 $d-q$ 軸" (仮称)が定義できる。また, $\theta_{s 1}$ $=\theta_{s 2}=0$ とすれば, "多相絶対変換静止 $d-q$ 軸"(仮称)も定 義できることになる。

$<2.3>$ 相軸上の電圧と六相絶対变換回転 $d-q$ 軸上の電 圧端子に加わる相電圧は(3)式および(4)式として表さ れるが，相電圧の一般式としては両者の和をとり(8)式の ように表すことにする。 


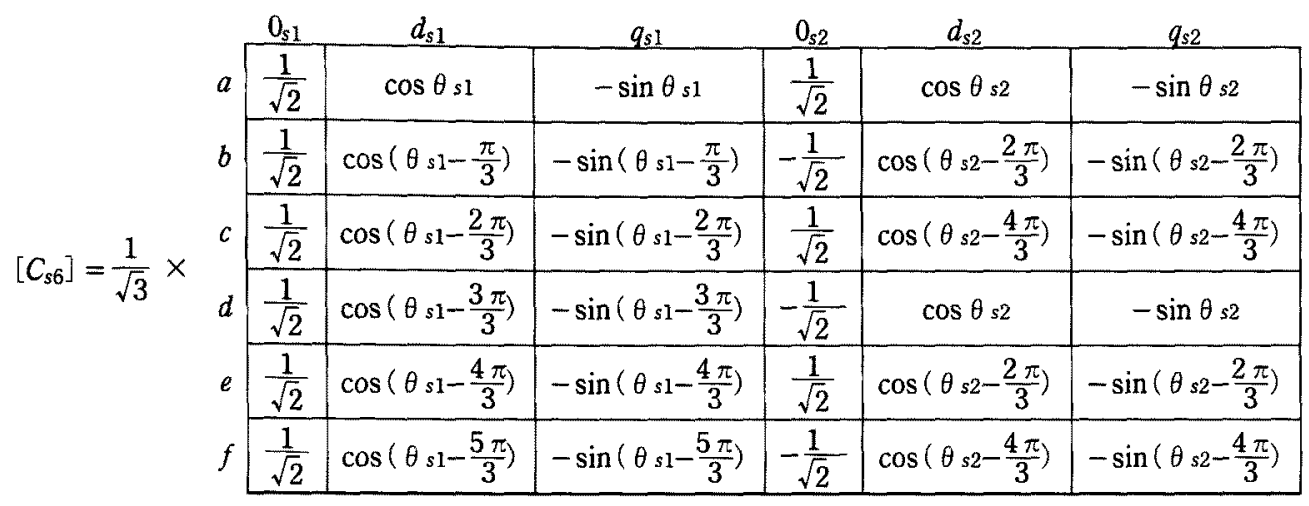

$$
\left[v_{p}\right]=\begin{array}{c|c|c|}
a & v_{a} \\
b & v_{b} \\
c & v_{c} \\
d & v_{d} \\
\hline e & v_{e} \\
\hline f & b & v_{a 1}+v_{a 2} \\
\hline & v_{f 1}+v_{b 2} \\
\hline & f & v_{c 1}+v_{c 2} \\
\hline & f & v_{d 1}+v_{d 2} \\
\hline v_{f 1}+v_{e 2} \\
\hline
\end{array}
$$

ここで，(7)式を適用して，相電圧 (8) 式を六相絶対変換回 転 $d-q$ 軸上に変換すると，以下のようになる。ただし，tは 転置行列を示す。

$$
\begin{aligned}
& {\left[v_{d q}\right]=\left[C_{s 6}\right]_{t}\left[v_{p}\right]}
\end{aligned}
$$

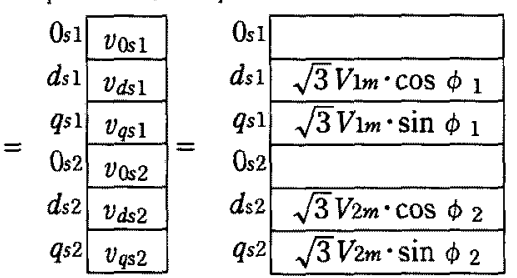

また，(9)式では各d-q軸の回転角速度を各々に対㐫する 回転磁界と同期させているので, 各座標軸の回転角度は (10)式および(11)式となる。

$$
\begin{aligned}
& \theta_{s 1}=\omega_{1} t \\
& \theta_{s 2}=\omega_{2} t
\end{aligned}
$$$$
\text { .................. (10) }
$$

(9)式より明らかなように，相軸上の電圧に対称六相交 流および二倍角対称六相交流が混在したとしても，六相絶 対変換回転 $d-q$ 軸上では，前者の電圧成分は基隻 $d-q$ 軸 に, 後者の電王成分は二倍角 $d-q$ 軸に割り当てられること になる。しかも，どの座標軸の電圧も周波数に無関係な直 流量となっており，定性的および定量的検討に便利である ことがわかる。

$<2.4>$ 電压方程式とトルクの式 （7）式を参考にし $\tau$, 六相PCIMに対寸る六相絶対変換回転 $d-q$ 軸を(12) 式 のように定義する。

$$
\left[C_{6}\right]=\left[\begin{array}{ll}
{\left[C_{s 6}\right]} & {[0]} \\
{[0]} & {\left[C_{r 6}\right]}
\end{array}\right]
$$

ここで， $\left[C_{s 6}\right]$ は固定子についての变換行列で (7) 式, $\left[C_{r 6}\right]$ は回転子についての変換行列で(13) 式となるが, 固

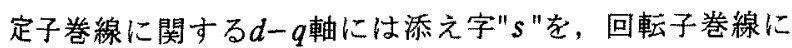
関保する $d-q$ 軸には添え字" $r$ "を付している。[0]は零行列 である。

$\left[C_{r 6}\right]=[(7)$ 式において, 座標軸 $a, b, c, \cdots, f$ を $g, h, i, \cdots, l k, d-q$ 軸および $\theta$ の添え字 "s"を" $r$ "に変更した式]

…...... (13) また，回転子各軸の回転角は，(14)式および(15)式となる。

$$
\begin{aligned}
& \theta_{r 1}=\theta_{s 1}-\theta=s_{1} \omega_{1} t-\phi \\
& \theta_{r 2}=\theta_{s 2}-2 \theta=s_{2} \omega_{2} t-2 \psi
\end{aligned}
$$

図1の解析モデルに従い，2p'極㧍よび $4 p^{\prime}$ 極としての定数 を考慮して，相軸上のインピーダンスを求めると(16)式と なる。

$\left[Z_{p}\right]=\left[\begin{array}{ll}{\left[Z_{s s p}\right]} & {\left[Z_{s r p}\right]} \\ {\left[Z_{s r p}\right]_{t}} & {\left[Z_{r r p}\right]}\end{array}\right]$

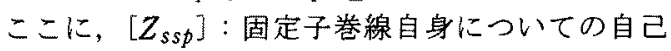

インピーダンス, $\left[Z_{s p p}\right]$ : 固定子巻線と回転子巻

線との閒の相互インピーダンス, $\left[Z_{r r p}\right]$ : 回転子

巻線自身の自己インピーダンス

個々の式については，図1の考察より容易に求めることが できるのでここでは紙面の都合もあり詳細は省略する。

したがって，六相絶対变換回転 $d-q$ 軸上のインピーダン スは(17)式となる。

$$
\begin{aligned}
{\left[Z_{d q}\right] } & =\left[C_{6}\right] t\left[Z_{p}\right] \\
& \equiv\left[\begin{array}{ll}
{\left[Z_{s s d q}\right]} & {\left[Z_{s r d q}\right]} \\
{\left[Z_{r s d q}\right]} & {\left[Z_{r r d q}\right]}
\end{array}\right]
\end{aligned}
$$

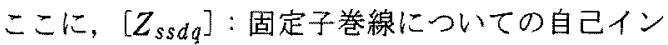
ピーダンス，[$\left[Z_{s r d q}\right]$ および $\left[Z_{r s d q}\right]$ : 固定子巻線

と回転子巻線との相互インピーダンス,

$\left[Z_{r r d q}\right]$ : 回転子巻線の自己インピーダンス

なお, 一般に零相軸には電流が流れないので, 以下の解 析においては零相軸を省略するものとする。

詳細は省略するが，（17）式より六相絶対変換回転 $d-q$ 軸 上のインピーダンス行列は，基準 $d-q$ 軸（ $2 p^{\prime}$ 極に対応）の 各要菜と二倍角 $d-q$ 軸 ( $4 p{ }^{\prime}$ 極に対応)の各要素とが完全に 独立してお互いに影響を及ぼさない形で導出される。ま た，(9)式のように電圧の式も，対称六相交流の成分と二 倍角対称六相交流の成分とが, 基準 $d-q$ 軸と二倍角 $d-q$ 軸 とに分かれるので，電圧方程式としてはそれぞれ別々な式 として取り扱うことができる(3)。さらに，文献(13)に示さ れるように，固定子鉄損は等価鉄損抵抗として容易に遒入 することができるので, 最終的な電圧方程式は, $2 p$ '極に 対しては(18)式，4p極に対しては(19)式として表すこと 


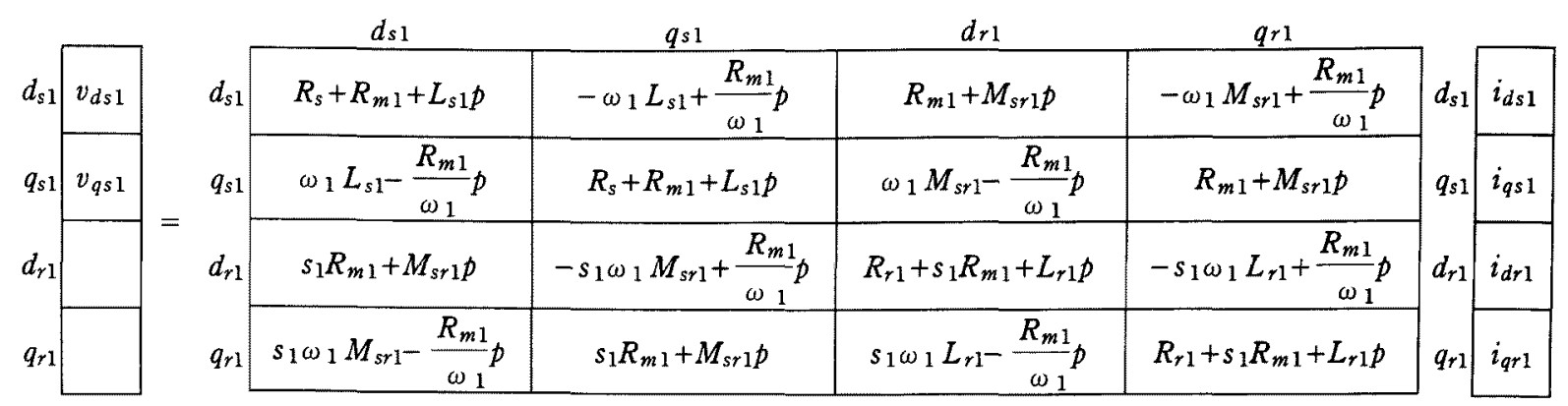

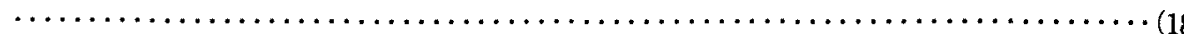

[(18)式において，座標軸および定数の添え字 "1"を"2"に変更した式]

ここに, $R_{s}$ : 一次巻線抵抗, $L_{s}$ : 一次巻線自己インダクタンス, $M_{s r}$ : 一次巻線と二次巻線との相互インダクタンス,

$R_{r}$ : 二次巻線抵抗, $L_{r}$ : 二次巻線自己インダクタンス, $R_{m}$ : 等価鉄損抵抗, $p:$ 微分オペレータであり, $2 p^{\prime}$ 極機と

しての定数には添え字 "1"を，4p’極機としての定数には添え字 "2" を付している。

ができる。両式は鉄損を考慮した $d-q$ 軸上方程式(13) と同一 の式の形となる。

電圧方程式が $2 p^{\prime}$ 極と $4 p^{\prime}$ 極とで別々に取り扱うことがで きるので，トルクの式もこれらの方程式から別々に求め加 え合わせればよいことになる。したがって，N·mで表した $2 p$ 極としてのトルクを $\tau_{n 1}, 4 p{ }^{\prime}$ 極としてのトルクを $\tau_{n 2}$ と すれば，合成トルク $\tau_{n}$ は

$$
\tau_{n}=\tau_{n 1}+\tau_{n 2}
$$

として表すことができる。ここに，

$$
\begin{aligned}
\tau_{n 1} & =p^{\prime}\left\{M_{s r 1}\left(i_{d r 1} i_{q s 1}-i_{q r 1} i_{d s 1}\right)\right. \\
& \left.-\frac{R_{m 1}}{\omega_{1}}\left(i_{q r 1} i_{q s 1}+i_{q r 1}{ }^{2}+i_{d r 1} i_{d s 1}+i_{d r 1}{ }^{2}\right)\right\}
\end{aligned}
$$

$\tau_{n 2}=2 p^{\prime}\left\{M_{s r 2}\left(i_{d r 2} i_{q s 2}-i_{q r 2} i_{d s 2}\right)\right.$

$\left.-\frac{R_{m 2}}{\omega_{2}}\left(i_{q r 2} i_{q s 2}+i_{q r 2}{ }^{2}+i_{d r 2} i_{d s 2}+i_{d r 2}{ }^{2}\right)\right\}$

また，固定子相軸上における電流 $\left[i_{p}\right]$ は， $d-q$ 軸上の 電流を

$$
[i d q s]_{t}=\begin{array}{|c|c|c|c|}
d_{s 1} & \multicolumn{1}{c}{q_{s 1}} & d_{s 2} & q_{s 2} \\
\hline i_{d s 1} & i_{q s 1} & i_{d s 2} & i_{q s 2} \\
\hline
\end{array}
$$

と表すことにすれば

$$
\left[i_{p}\right]=\left[C_{s 6}\right]\left[i_{d q s}\right]
$$

として求めることができる。

$<2.5>$ 定常状態における電圧方程式と等価回路定常 状態では, 時間 $t$ の関数とならない成分の微分は 0 となるの で，(18)式および(19)式において $p=0$ とすればよい。定常 状態における電圧方程式も，鉄損を考慮したd-q軸上の電 圧方程式(13) と同一の形をしているので，これらに対する等 価回路も同一の形で表すことができる。すなわち，2p'極 の場合の定常状態に対する実効值表示の等価回路は図 3 と なり，通常のT形等価回路と一致する。ただし，同図にお いて, $V_{s 1}$ は相電圧, $I_{s 1}$ は一次電流, $I_{r 1}$ は二次電流であ

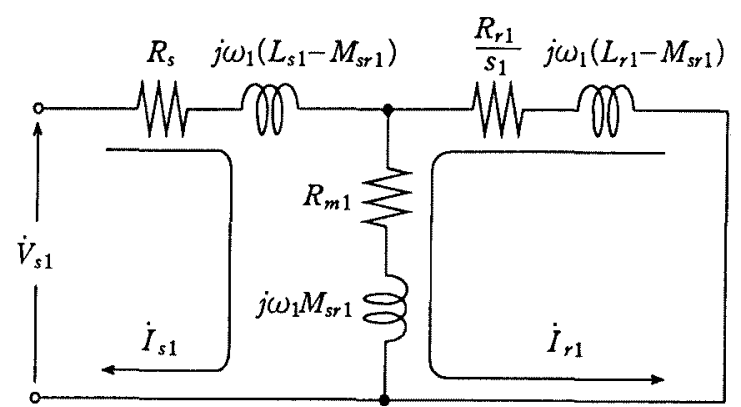

図32 $2 p^{\prime}$ 極運転時の等価回路

Fig. 3. Equivalent circuit for $2 p^{\prime}$-pole operation.

る。同様に，4p’極に対寸る等価回路は，図3において各 定数および電流，電圧の添え字" 1 "を" 2 "に変更したものと なる。各定数はすべて一次側に換算された量とみなしてお $\eta$, 等価回路定数之六相絶対変換回転 $d-q$ 軸上の電圧方程 式の定数との関係も明確となった。

以上により，六相PCIMの任意の運転状態における特性 を容易に解析し得る一方法が確立できた。

\section{3. 試作機の仕様と実験方法}

$<3.1>$ 試作機の概要 表1に試作した六相PCIMの仕 様を示す。試作機は実験用の小形機で，直接EVに搭載す るものではない。極数は，負荷装置の都合上8極および4極 に切換が可能となっている。定格電圧は相電圧で定めてい るが，これは極数の切換を電圧の位相差を変更することに よって行うことから, 線閒電圧と相電圧との関係が一定と ならないためである。本試作機では，850 r pmを基底速度 とし, 極数切換を前提に速度比 $1: 4$ 程度の範囲で定出力運 転することを目標としている。

<3.2> 実験装置の構成上実験方法 各極数に対する 定常特性は既に明確となっている(9)ので，ここでは前記の 解析法に対する実験的検証として，8極定常運転加ら4極定 常運転への切換時の過渡状態 (以下, 8 極 $\rightarrow 4$ 極切換運転と 略記) および，対称六相交流と二倍角対称六相交流とが混 
表 1 試作機の仕様

Table 1. Specifications of the test machine.

\begin{tabular}{|c|c|}
\hline 定 & 続 \\
\hline 相 & 六相 \\
\hline 極 & 8 極 $\nearrow 4$ 極 \\
\hline 出 & $0.6 \mathrm{~kW}$ \\
\hline 周 波 & $60 \mathrm{~Hz}$ \\
\hline 相 電 压 & $(100 / \sqrt{3}) V$ \\
\hline 電 流 & $5.0 \mathrm{~A} / 2.9 \mathrm{~A}$ \\
\hline 回 転 数 & $850 \mathrm{rpm} / 1730 \mathrm{rpm}$ \\
\hline 絶緑 & $\mathrm{F} \quad$ 種 \\
\hline 保護 形式 & 開 放 保 護 形 \\
\hline 固定子鉄心内径 & $90.0 \mathrm{~mm}$ \\
\hline 鉄 心 長 & $78.0 \mathrm{~mm}$ \\
\hline ギャップ長 & $0.3 \mathrm{~mm}$ \\
\hline 固定子スロット数 & 36 \\
\hline 回転子スロット数 & 44 \\
\hline 斜めス口ッ卜比 & $\begin{array}{l}\text { 固定子スロットピッチに対 } \\
\text { して1.0 }\end{array}$ \\
\hline 固定子整線方式 & 六相二層分布重ね巻 \\
\hline 回転子卷線形式 & 加 $=$ 形 \\
\hline
\end{tabular}

在する状態(以下，8極／4極同時運転と略記）における特性 について検討を行うことにする。

図4に実験装置の構成を示す。試作した六相PCIMを瞬 時変動トルク検出器を介し, 負荷装置である直流発電機に 直結する。軸端のフライホイールは, 実際のEVの車体重 量, 加速時間などを勘案して設計したので, 過渡状態の卜 ルク変動をかなり正確に測定できると考えている。なお， 試作した六相PCIM $\sigma G D^{2}$ は, 設計值で $0.015 \mathrm{kgf}-\mathrm{m}^{2}$, 六 相PCIMを除く回転部分の $G D^{2}$ は, 約 $0.8 \mathrm{kgf}-\mathrm{m}^{2}$ であ る。トルクの時間に対する応答波形は，トルク検出器(小 野測器製DP-200)の出力を瞬時トルク変換器 (同PD-
860)を用いて電圧出力とし、メモリレコーダにより記録 する。このトルク検出器および変換器は, 軸のねじれ角を 検出してトルクを測定するもので, 瞬時変動トルク測定専 用に設計されたものである(14)。サンプリング周波数は検出 器内部蒾車の歯数 (120) と毎秒回転数との積となる。例え ば，1000 rpmでは，サンプリング周波数が $2 \mathrm{kHz}$ となり， 本実験システムにおけるトルク応答の測定には十分な精度 で対応できているといえる。また，電圧および電流の時間 に対する忘答波形の測定は，各相巻線にて行い，メモリレ コーダにより記録する。

実験には電源装置として，キャリア周波数 $12 \mathrm{kHz}$, 定格 容量5.5kVA，オールディジタル制御，正弦波近似PWM方 式の三相はん用電圧形INVを2台使用した。この2台のINV を単相変圧器を 3 台組合せた六相混成変圧器 (仮称) 一接続 することにより，対称六相交流扝よび二倍角対称六相交流 が得られるようになっている。同図において開閉器SW1の みが閉じている場合には，六相PCIMに対称六相交流が印 加されることになり，開閉器SW2のみが閉じている場合に は，二倍角対称六相交流が印加されることになる。また， SW1およびSW2を同時に閉じた場合には，六相PCIMに両 方の電圧成分が混在した状態で印加されることとなり，8 極 $/ 4$ 極同時運転を行い得ることになる。過渡特性の検証 はここらの開閉器を開閉することにより行うことにな る。なお, 各INVの出力電圧の微調整用として, 容量の大 きいスライダックを用いている。

表 2 に測定およびシミュレーション時の条件をまとめて 示す。運転周波数は，実際に極数切換を行う回転数相当と

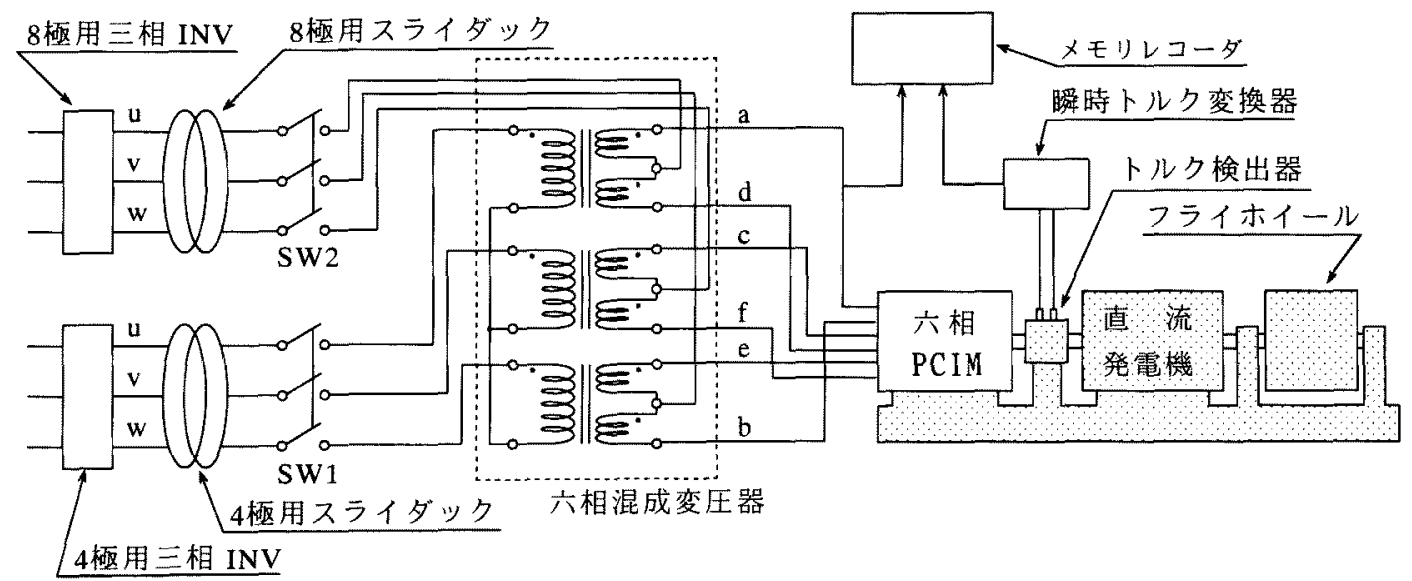

図4実験装置の構成図

Fig. 4. Arrangement of experimental apparatuses.

表2 測定およびシミュレーション条件

Table 2. Condition for measurement and simulation.

\begin{tabular}{c|c|c}
\hline & 8 極 $\rightarrow 4$ 極切換運転 & 8 極 $/ 4$ 極同時運転 \\
\hline 相電圧 $/$ 周波数 & 8 極 $:(80 / \sqrt{3}) \mathrm{V} / 90 \mathrm{~Hz}, 4$ 極 $:(60 / \sqrt{3}) \mathrm{V} / 45 \mathrm{~Hz}$ \\
\hline 電圧 位 相 & $\phi_{1}=88^{\circ}, \phi_{2}=285^{\circ}$ & $\phi_{1}=208^{\circ}, \phi 2=260^{\circ}$ \\
\hline 負 & $0.200 \mathrm{kgf} \cdot \mathrm{m}$ & $0.260 \mathrm{kgf} \cdot \mathrm{m}$ \\
\hline 荷 & $0.0542 \mathrm{sec}$ & \\
\hline
\end{tabular}




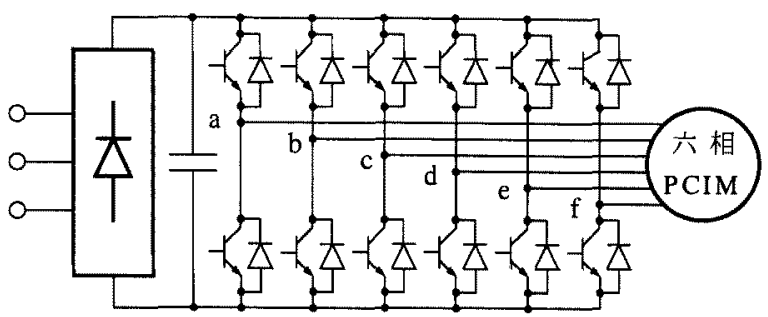

図5 六相インバータによるシステム構成

Fig. 5. System arrangement using six-phase inverter.

し，8極 $90 \mathrm{~Hz} ， 4$ 極 $45 \mathrm{~Hz}$ とした。また，電圧については， 磁気飽和の影響が生じないように，各々の周波数に対する 定格電圧の $80 \%$ とした。なお，実用上は図4に示す 2 台の三 相INVおよび六相混成変圧器の部分を図5に示すような六 相INVに置き換え，極数切換の制御を自動的に行うことに なるが(10)，詳細については今後の課題とする。

\section{4. 実験結果とシミュレーション結果との比較検討}

$<4.1>8$ 極 $\rightarrow 4$ 極切換運転時における検証 図6に, 8 極 $\rightarrow 4$ 極切換運転時に扔ける相電圧, 電流孔よびトルク波 形の実測結果とシミュレーション結果との比較を示す。

シミュレーションは，(18)式および(19)式を状態変数方 程式の形に変形し, 数值計算によって行った。まず, 各定 数および電圧を与えた後に, 時間 $t$ に対する六相絶対変換回 転 $d-q$ 軸上の電流值を各極数について各々独立に求め, こ の電流を(24) 式に代入して相電流の瞬時值を，（20）式に代 入してトルクの瞬時值を求めたものである。また，表 $3 に$ シミュレーションに用いた等価回路定数を示す。この定数
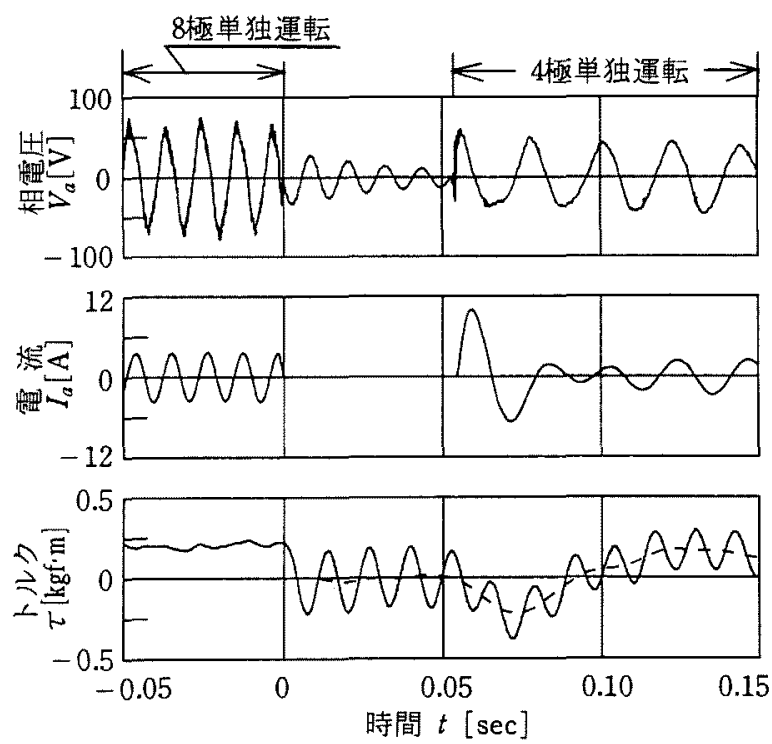

(a) 8 極 $\rightarrow 4$ 極切換運転時の実測結果
は，前論文(9)にしたがって，擬似正弦波法により求めたも

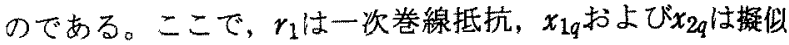
正弦波漏れリアクタンス， $x_{m q}$ は擬似正弦波励磁リアクタ ンス，r $r_{2 q}$ は擬似正弦波二次抵抗であり，図3の定数との関 係は，表3の闌外に示寸通りである。なお，シミュレーシ ヨンにおいては、計算の簡単化のために鉄損を無視し，有 効トルク係数 ${ }^{(9)} K \tau=1$ としている。

図6においては，8極単独運転の状態から，時間 $t=0 \mathrm{sec} に$

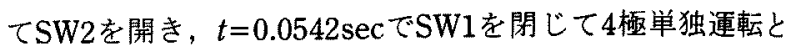
している。このため, $t=0 \sim 0.0542 \mathrm{sec} の$ 間にて8極として の残留電圧が現れ， $t=0.0542 \mathrm{sec}$ 以降では4極としての電圧 印加時の過渡現象が現れていることになる。同図の相電圧 抢よび電流波形については，シミュレーション結果の最大 值が実測結果より若干大きくなっているものの，8極の残 留電圧, SW1投入後の過渡現象などの傾向が良好に一致し

表 38 極 $\rightarrow 4$ 極切換運転時の特性算定に用いる擬 似正弦波等価回路定数

Tabel 3. Constants of the quasi-sinusoidal wave equivalent circuit for simulation at pole change operation from 8 -pole to 4 -pole.

\begin{tabular}{c|c|c}
\hline & 8極側定数 $(90 \mathrm{~Hz})$ & 4 極側定数 $(45 \mathrm{~Hz})$ \\
\hline$r_{1}[\Omega]$ & \multicolumn{2}{|c|}{1.69 (at $\left.31.4^{\circ} \mathrm{C}\right)$} \\
\hline$x_{1 q}=x_{2 q}[\Omega]$ & 3.92 & 2.25 \\
\hline$x_{m q}[\Omega]$ & 21.4 & 36.4 \\
\hline$r_{2 q}[\Omega]$ & 1.33 (at $\left.31.4^{\circ} \mathrm{C}\right)$ & 1.07 (at $\left.31.4^{\circ} \mathrm{C}\right)$ \\
\hline
\end{tabular}

ただし，図 3 中の定数と, 擬似正弦波等価回路定数

との間には以下の関倸がある。

$R_{s}=r_{1}, R_{r}=r_{2 q}, \omega\left(L_{s}-M_{s r}\right)=x_{1 q}$,

$\omega\left(L_{r}-M_{s r}\right)=x_{2 q}, \quad \omega M_{s r}=x_{m q}$
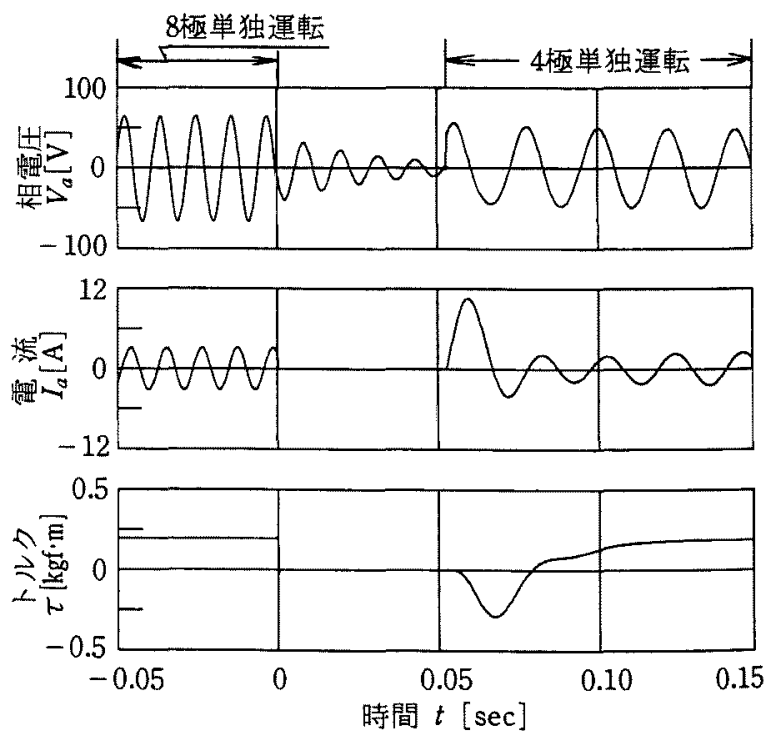

(b) 8 極 $\rightarrow 4$ 極切換運転のシミュレーション結果

図6 8 極 $\rightarrow 4$ 極切換運転の実測結果とシミュレーション結果との比較

(8極 : $(80 / \sqrt{3}) \mathrm{V} / 90 \mathrm{~Hz}, 4$ 極 : $(60 / \sqrt{3}) \mathrm{V} / 45 \mathrm{~Hz})$

Fig. 6. Comparison between measured results and simulated results at pole change operation from 8 -pole to 4 -pole. 
ていることがわかる。

一方, トルクの赛測值においては， $t=0$ sec以降に大きな 眽動が現れている。この脈動トルクの周波数は, FFTアナ ライザによる解析の結果, 測定システムの共振周波数 (78 $\mathrm{Hz}$ )と一致した。またこの脈動トルクは約1秒閒で減衰す ることも確認しており，機械系の影響によって生じたもの と考えられる。したがって， $t=0 \mathrm{sec}$ 以降，実際に六相 PCIMが発生しているトルクは，同図に示す破線のように なっているものと想定でき, 若干の時間的な差が生じてい る䇢所もあるが，シミュレーション結果と同様な傾向を示 していることがわかる。なお，回転数は，測定期間中にお いてほぼ1280rpm一定であった。

このように，本方法を用いることにより，六相PCIMの 各極単独運転時の定常状態および過渡状態での特性が容易 にシミュレーションできるとともに，極数切換時における 連続的な検討が十分に可能であることがわかる。

実測結果とシミュレーション結果との差異については, 各定数の誤差, 六相混成変玨器のインピーダンスの影響な どが考えられるが，六相絶対変換回転 $d-q$ 軸の基礎理論に 対する検証という目的に対しては，満足のいく結果が得ら れたものと考えている。

$<4.2>8$ 極 $/ 4$ 極同時運転時における検証図7に 8 極 $/ 4$ 極同時運転より8極側電源のみを開放した場合にお ける実測結果とシミュレーション結果との比較を示す。シ ミュレーションの方法は前節と同椂であるが，等価回路定 数は測定時の巻線温度, 定常状態の電流值および滑り周波 数の差異を勘案して ${ }^{(9)}$ ，表4に示す值を用いている。

図7においては，8極／4極同時運転の状態から，t=0 sec においてSW2を開いて4極単独運転としている。したがっ
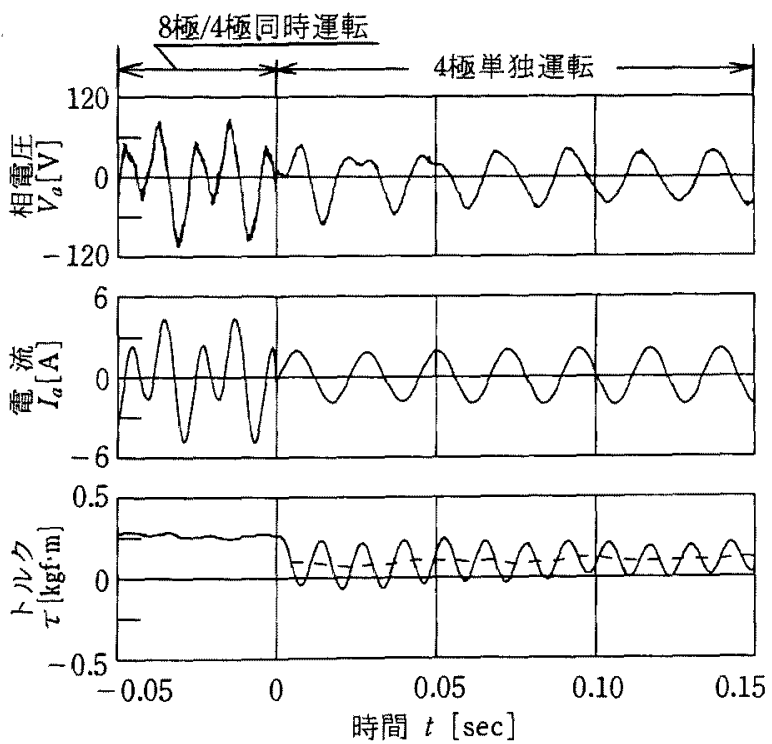

(a) 8 極 $/ 4$ 極同時運転の実測結果

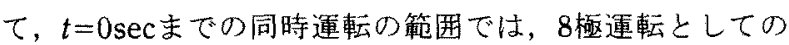
相電圧，電流およびトルクと，4極運転としてのそれらと が重极合わさっていることになる。また， $t=0 \sec$ 以降の相 電圧波形においては，図6に現れているような8極としての 残留電圧と4極単独運転としての相電圧とが重㸚わさっ ていることになる。一方，実測結果のトルク波形について は，図6のトルク波形と同様に，機械系の影響による脈動 トルクが生じており，実際に六相PCIMが発生しているト ルクは，破線で示すようになっているものと考えられる。 回転数は，測定期間中においてほぼ1300rpm一定であっ た。

図7より明らかなように，8極／4極同時運転の定常状 態，8極の電源開放に伴う過渡状態などにおいて，実測結 果とシミュレーション結果とが良好な一致を示しているこ とがわかる。したがって，六相PCIMの両極同時運転にお

表 48 極 $/ 4$ 極切換運転時の特性算定に用いる擬 似正弦波等価回路定数

Tabel 4. Constants of the quasi-sinusoidal wave equivalent circuit for simulation at 8 -pole / 4-pole dual operation.

\begin{tabular}{c|c|c}
\hline & 8 極側定数 $(90 \mathrm{~Hz})$ & 4 極側定数 $(45 \mathrm{~Hz})$ \\
\hline$r_{1}[\Omega]$ & \multicolumn{2}{|c|}{$1.74\left(\right.$ at $\left.39.3^{\circ} \mathrm{C}\right)$} \\
\hline$x_{1 q}=x_{2 q}[\Omega]$ & 4.00 & 2.59 \\
\hline$x_{m q}[\Omega]$ & 21.3 & 36.0 \\
\hline$r_{2 q}[\Omega]$ & $1.34\left(\right.$ at $\left.39.3^{\circ} \mathrm{C}\right)$ & $0.942\left(\right.$ at $\left.39.3^{\circ} \mathrm{C}\right)$ \\
\hline
\end{tabular}

ただし, 図 3 中の定数上, 擬似正弦波等価回路定数

との間には以下の関係がある。

$R_{s}=r_{1}, R_{r}=r_{2 q}, \omega\left(L_{s}-M_{s r}\right)=x_{1 q}$,

$\omega\left(L_{r}-M_{s r}\right)=x_{2 q}, \quad \omega M_{s r}=x_{m q}$
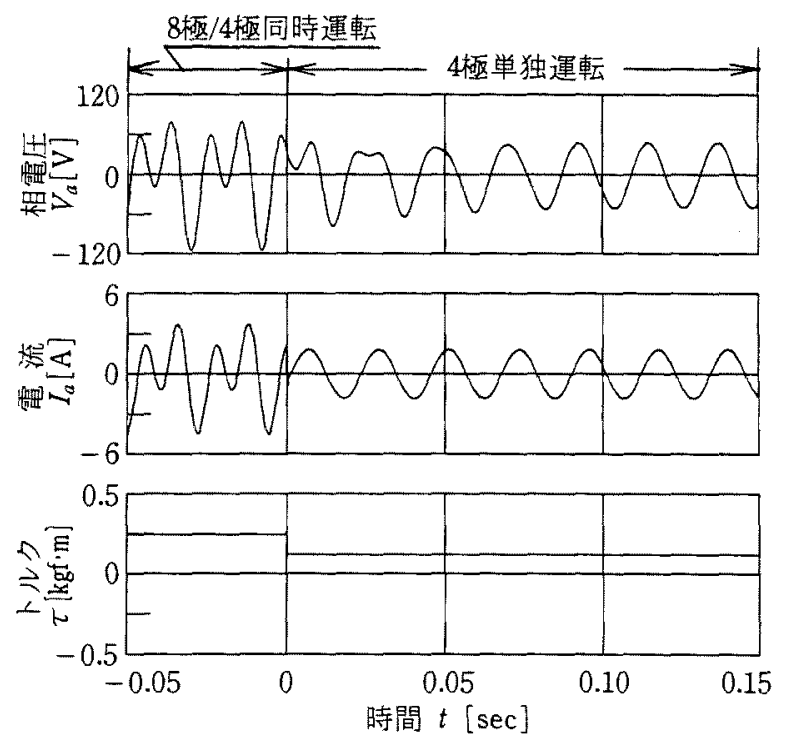

(b) 8 極 4 極同時運転のシミュレーション結果

図7 8極 $/ 4$ 極同時運転の実测結果とシミュレーション結果との比較

$(8$ 極: $(80 / \sqrt{3}) \mathrm{V} / 90 \mathrm{~Hz}, 4$ 極: $(60 / \sqrt{3}) \mathrm{V} / 45 \mathrm{~Hz})$

Fig. 7. Comparison between measured results and simulated results at 8 -pole / 4-pole dual operation. 
いて，各々の極数に対応する定常および過渡特性は，それ ぞれ独立に決定されること, 電圧, 電流およびトルク波形 などは, 各極単独運転時の波形を加え合わせたものになる ことも明白であり，任意の運転状態に対して本理論の妥当 性が検証できたことになる。

これらの検証結果より, 提案した解析理論を用いること により, 過渡現象を抑制するための極数切換方式, 可変速 制御方式など, 六相PCIMのより詳細な検討が可能になっ た。

\section{5. あとがき}

以上, 電気自動車用六相PCIMの解析法として, 六相絶 対変換回転 $d-q$ 軸を提案し, その物理的意味を明確にする とともに, 極数比 $2: 1$ 極数切換が可能となる六相PCIMの 解析および実験的検証などを行った。本論文の要点をまと めると以下のようである。

（1）六相絶対変換回転 $d-q$ 軸は, 基準座標系において任 意の速度で回転する直交二軸, 二倍角座標系において任意 の速度で回転する直交二軸およびそれらの零相軸から定義 でき,その物理的意味が明確となった。

（2）六相PCIMを六相絶対変換回転 $d-q$ 軸により解析す ると, 基準 $d-q$ 軸上に対称六相交流に対する電圧方程式 (高速側極数に対応) が得られ，二倍角 $d-q$ 軸上に二倍角対 称六相交流に対する電圧方程式 (低速側極数に対応) が得ら れることになる。両者はお互いに独立であり非干涉とな る。

（3）対称六相交流および二倍角対称六相交流が各々単独 に，または同時に加えられている場合でも, 電流, トルク 特性などはそれぞれ独立に, かつ容易に求めることがで き, 最終的にそれらを加え合わせれば良い。したがって， 定常状態および過渡状態を問わず, 統一的かつ連続的な検 討が可能となった。

（4）実験結果とシミュレーション結果との比較では，両 者が良好な一致を示し, より詳細な六相PCIMの特性解 析, 制御方式の構築などに適用できる簡便なる一方法を確 立できた。また, 本理論は基本的に六相巻線から出発して いるので, 一般的な三相極数切換IM, 大容量化に伴う多重 (多相) 巻線IM(15) などにも十分に応用できるものと考えて いる。

なお，六相PCIMの極数切換を含む全体の速度制御方 式，極数切換時の過渡現象の抑制方法などについては, 今 後詳細に検討を行っていく予定である。

最後に, 本論文の基礎となる実験および資料の整理など に協力いただいた中部大学工学部電気工学科卒業研究生に 謝意を表します。

(平成8年1月 25 日受付, 平成8年6月 20 日再受付)

文献

（1）藤原 昇：「電気自動車用モー夕の最新動向」, ’ 92 モー夕技
術シンポジウム, A2-1-1(平4-4)

(2) 名取 一雄 : 「活発化する電気自動車の技術開発」, 電学誌, 111 巻 1 号 (平3-1)

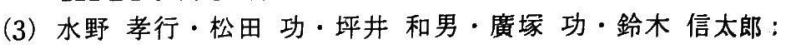
「電気自動車用極数切換誘導電動機の六相絶対変換回転 $d q$ 軸 による解析」, 電気学会回転機研資, RM-94-101 (平6-10)

（4）坪井和男 - 廣塚功 - 鈴木 信太郎 - 松井景樹 - 水野孝行 . 松田功:「電気自動車用極数切換誘導電動機の試作と基本 トルク特性」, 電気関倸学会東海支部連大, No.205 (平6-10)

（5）坪井和男 - 水野 孝行 - 廣塚功 - 鈴木 信太郎 - 松井景樹 松田 功：「電気自動車用六相極数切換誘導電動機の最大卜 ルク特性」, 平7電気学会全大, No.972

（6）水野孝行 ·松田功 - 坪井和男 - 廣塚功 - 鈴木 信太郎: 「電気自動車用六相極数切換誘導電動機の巻線方式と起磁力 の検討」, 平7電気学会全大, No.973

（7）鈴木 信太郎 - 坪井和男 - 廣塚功 - 水野孝行 - 松田功: 「電気自動車用極数切換誘導電動機の漂遊負荷損に関する実 験的検討」, 平7電気学会産応全大, No.T-11

（8）跉木 信太郎 - 廣塚 功 - 坪井和男 - 水野孝行 - 松田功: 「電気自動車用六相極数切換誘導電動機の擬似正弦波法によ る滑りートルク特性算定法」, 電気学会回転機研資, RM-95 -95 (平7 -10 )

（9）水野孝行 ·坪井和男 ·廣塚功 - 鈴木 信太郎 - 松田功 - 小 林 忠夫：「電気自動車用六相極数切換誘導電動機の基本原 理と最大トルク特性」, 電気学会論文誌D, 116巻, P256 (平8 $-3)$

(10) 森 真人 - 永山和俊 - 水野 孝行 - 足利 正 - 松田 功：「電 気自動車用極数切換誘導電動機の一制御法」, 電気学会半導 体電力変換研資, SPC-95-116(平7-12)

(11) 坪井 和男：「多相絶対変換対称軸と回転機テンソル解析一 の応用」, 昭52電気学会全国大会, No.607

(12) 坪井和男 - 秋山勇治・水野孝行：「誘導電動機の回転子 スロット数による始動時異常現象の一般解析」, 電気学会論 文誌B, 100巻, P549(昭55-9)

(13) 水野孝行 - 高山順一・市岡 忠士 - 寺嶋 正之：「固定子鉄 損を考虑した誘導電動機の非干渉制御法」, 電気学会論文誌 $\mathrm{D}, 109$ 巻, $\mathrm{P} 841$ (平元 -11 )

(14) 小野測器 : '93〜'94総合カタログ, P102〜119

(15) 多重化電力変換方式調查専門委員会：「多重化電力変換器と その応用技術」, 電気学会技術報告, 第556号, (平7-7) 
坪井和男（正員）1944年4月11日生。1973年3月中部

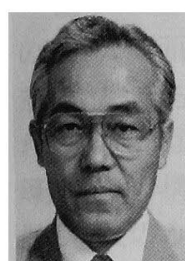
工業大学 (現, 中部大学) 大学院工学研究科 電気工学専攻修士課程修了。同大学講師, 助教授を経て, 1984年4月中部大学教授, 現在に至る。主として, 誘導電動機および 同期電動機の解析と特性改善に関する研究 に従事。工学博士 (九州大学)。1981年電 気学会論文賞受賞。IEEE会員。

席塚功（正員）1961年8月29日生。1986年3月中部 $\frac{2}{2}$ 大学大学院工学研究科電気工学専攻博士前 期課程修了。同年 4 月三菱電機㑣入社。同年 10 月同社退社。1990年3月中部大学大学院 工学研究科電気工学専攻博士後期課程満期 退学。同年4月同大学助手, 1993年4月同 講師, 現在に至る。工学博士。電気設備学 会会員。

鈴木信太郎（准員）1970年9月19日生。1994年3月中 $\int_{a}^{4}=$ 部大学工学部電気工学科卒業。1996年3月 中部大学大学院工学研究科電気工学専攻博 士前期課程修了。同年4月アイシン精機怢 入社, 現在に至る。
足利正（正員）1954年12月21日生。1975年3月秋

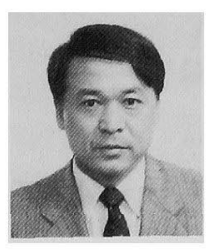
田工業高等専門学校電気工学科卒業。同年4 月烌明電舎入社。現在, 同社電動カシステ ム工場にて, 主として電動機制御の研究開 発に従事。1992年オーム技術賞受賞。

松田功（正員）1944年8月12日生。1970年3月山 梨大学工学部電気工学科卒業。同年 4 月(㑣) 明電舎入社。現在, 同社電動カシステム工 場にて, 回転機の研究開発に従事。 